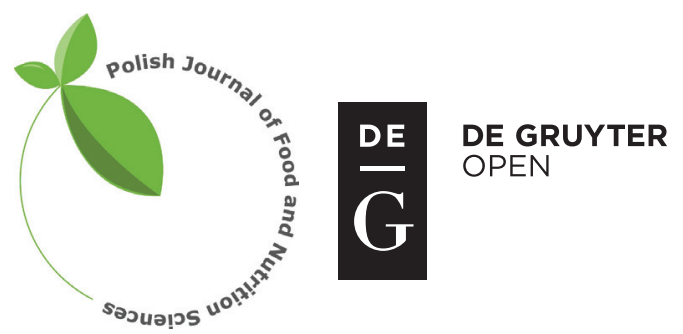

Pol. J. Food Nutr. Sci., 2018, Vol. 68, No. 4, pp. 289-297

DOI: $10.1515 /$ pjfns-2018-0005 http://journal.pan.olsztyn.pl

Original research article

Section: Food Chemistry

\title{
Effect of Dry Heat Puffing on Nutritional Composition, Fatty Acid, Amino Acid and Phenolic Profiles of Pseudocereals Grains
}

\author{
Luz María Paucar-Menacho ${ }^{1}$, Montserrat Dueñas ${ }^{2}$,Elena Peñas ${ }^{3}$, Juana Frias $^{3}$, Cristina Martínez-Villaluenga ${ }^{3 *}$
}

\author{
${ }^{1}$ Departamento de Ingeniería Agroindustrial, Facultad de Ingeniería, \\ Universidad Nacional del Santa, Av. Universitaria s/n Urb. Bella Mar, Nuevo Chimbote, Ancash, Perú \\ ${ }^{2}$ Research Group on Polyphenols, Nutrition and Bromatology Unit, Faculty of Pharmacy, \\ University of Salamanca, Campus Miguel Unamuno, 37007 Salamanca, Spain \\ ${ }^{3}$ Institute of Food Science, Technology and Nutrition (ICTAN-CSIC), Juan de la Cierva 3, 28006 Madrid, Spain
}

Key words: pseudocereals, amino acids, fatty acids, polyphenols, dry heat puffing

The impact of puffing on nutritional composition and phenolic profiles of kiwicha (Amaranthus caudatus L.) and quinoa (Chenopodium quinoa Willd.) was investigated. Popped kiwicha showed increased protein and lipid contents and lower contents of carbohydrates compared to the untreated grains. Higher lipid, ash and carbohydrates contents and a decreased protein content were observed after puffing of quinoa. Fatty acid profile and $\omega-6 / \omega-3$ ratio was not affected by puffing, although it was observed a healthier ratio in quinoa (7:1) compared to kiwicha (65:1). Thermal treatment reduced essential amino acid contents and protein quality of both grains, although amino acids content remained adequate according to FAO/WHO requirements for adults. Puffing decreased hydroxybenzoic and hydroxycinnamic acids content of both pseudocereals. Flavonoid levels were negatively affected by puffing in kiwicha while a noticeable increase was observed in popped quinoa. In summary, puffing of kiwicha and quinoa grains is an alternative processing method to obtain expanded products or precooked flours of adequate nutritional value.

\section{INTRODUCTION}

Recently, production of quinoa and amaranth, native to the Andean region (Bolivia, Perú and Ecuador), has crossed continental boundaries being also cultivated in USA, Argentina, Europe, Africa and Canada. The consumption of these pseudocereals in high-income countries is increasing although is still low compared with the main producer countries. These grains are consumed processed and semi-processed (popped, flaked, shredded, baked, etc.) and today they also have a key role in the gourmet cuisine. Food industry and consumers have shown a recent interest in these ancient grains mainly due to their nutritional value and their potential use as gluten-free ingredients. Quinoa and amaranth grains are notable as good sources of quality proteins with high levels of essential amino acids (EAA) [Taylor et al., 2014]. Protein from these grains contains more lysine, methionine and cysteine than most food proteins sources of plant origin [Ruales \& Nair, 1992]. Quinoa and amaranth have higher proportions of soluble dietary fiber than cereals, and the composition of their fiber resembles that of fruits, vegetables and legumes [Lamothe et al., 2015]. These grains are rich in polyunsaturated fatty acids [Peiretti et al., 2013] as well as in minerals such as iron,

\footnotetext{
* Corresponding Author: Tel.: +34 9125876 01; Fax: +34 915644853

E-mail: c.m.villaluenga@csic.es
}

copper, manganese and zinc [Nascimento et al., 2014]. Quinoa and amaranth are also important source of flavonoids, mainly glycosides of the flavonols (kaempferol and quercetin) and phenolic acids [Tang et al., 2015; Repo-Carrasco-Valencia et al., 2010].

Heat-induced puffing (popping) is a low cost technology that consists in the application of heat at atmospheric pressure giving rise to high internal pressure due to water vaporization causing the breaking of pericarp and expansion of grain endosperm [Song \& Ecknoff, 1994]. Puffed grains are widely used as ready-to-eat products or as ingredients in snack formulations, and their demand is currently increasing because of changing life styles. Processing of pseudocereals must adopt low cost technologies to produce traditional or innovative final products for populations of either developing or economically rich countries. Physical, structural and chemical modifications occur during the puffing process. Puffed grains undergo dehydration, starch gelatinization, increase of volume and textural changes [Hoke et al., 2007]. In addition, the puffing increases digestibility and technological functionality of starch and proteins [Gamel et al., 2006; Zapotoczny et al., 2006] and produces volatiles with pleasant flavor [Gamel \& Linssen, 2008]. Due to these positive changes puffing has been proposed to obtain amaranth flours to be used as ingredients in bakery products (bread and cookies) with novel textures and flavors [de la Barca et al., 2010]. From a nutri- 


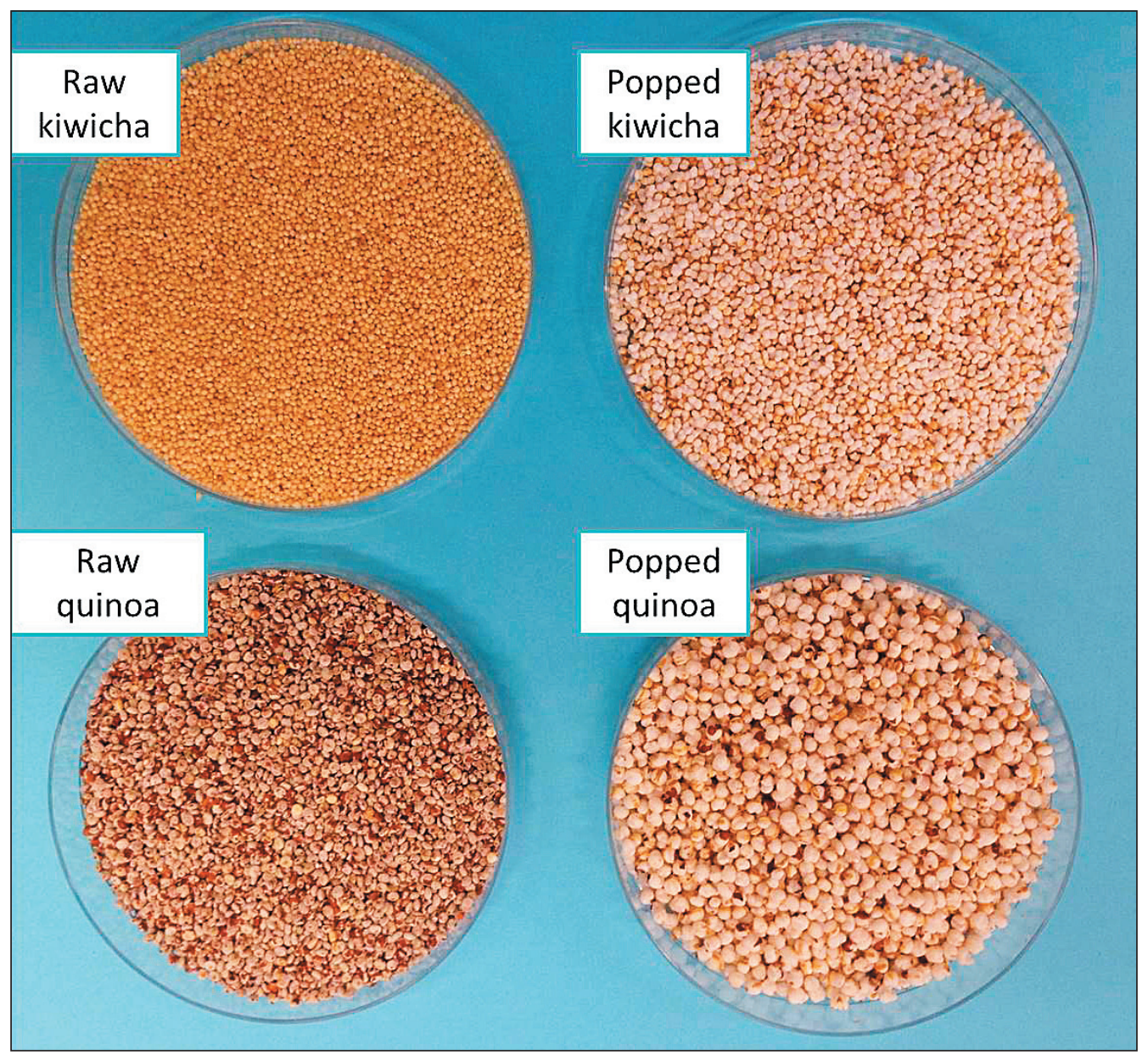

FIGURE 1. Raw and popped kiwicha and quinoa grains.

tional perspective, previous studies have shown that puffing of amaranth grains causes thermal degradation of amino acids [Gamel et al., 2004], B-group vitamins [Murakami Yutani et al., 2014], and phenolic acids [Ogrodowska et al., 2012]. Nonetheless, the effect of dry heat puffing on nutritional quality and phenolic profile has not yet been reported for quinoa or has not been completely studied for kiwicha (Amarathus caudatus L.), the most important Andean species of amaranth. Improving the quality of popped quinoa and kiwicha products can be achieved by understanding the changes that occur during the puffing process. Therefore, overall objective of this research was to study the effect of heat-induced puffing on the proximate, fatty acid and amino acid composition, protein quality and phenolic compounds of quinoa and kiwicha grains.

\section{MATERIALS AND METHODS}

\section{Materials}

Saponin-free quinoa (Chenopodium quinoa var. Pasankalla) and kiwicha (Amaranthus caudatus var. Centenario) grains were obtained from Cereals and Native Grains Program (Peru). All chemicals were purchased from either Sigma-Aldrich (Madrid, Spain) or Fisher Scientific (Madrid, Spain) unless otherwise stated. The standards, vanillic acid, trans-p-coumaric acid, quercetin 3-O-rutinoside, quercetin
3-O-glucoside and kaempferol 3-O-rutinoside were obtained from Extrasynthese (Genay, France).

\section{Preparation of popped kiwicha and quinoa grains}

Grains (40 g) were treated in a lab puffing system. Puffing took place in an expansion chamber were grains came into contact with hot air at $180^{\circ} \mathrm{C}$ for $2 \mathrm{~min}$. This treatment was considered optimal because it led to maximum expansion yield. Figure 1 shows raw and popped kiwicha and quinoa grains obtained in the present study. Three independent replicates were obtained for each grain. Popped and raw grains were ground in a coffee mill (Moulinex, Madrid, Spain), passed through a 30 -mesh sieve and stored at $-20^{\circ} \mathrm{C}$ in plastic bags under vacuum for further analysis.

\section{Proximate analysis}

Proximate composition of raw and popped flour was determined following AOAC methods including moisture (method 925.10), protein (method 920.87) and ash (method 923.03) [AOAC, 2005]. Fat content was determined by Soxhlet extraction using petroleum ether and a gravimetric method. The protein content of samples was calculated using 5.70 and 5.85 for quinoa and kiwicha flours, respectively, as the conversion factor [USDA, 2016]. Carbohydrates were calculated by difference: 100-(content of protein + content of fat + content of ash in $100 \mathrm{~g}$ of dry weight (dw)). All measurements were done in triplicate. 


\section{Determination of fatty acid composition}

The oil was removed from samples using a Soxhlet apparatus (petroleum ether, $8 \mathrm{~h}$ ). The fatty acid profile of extracted oil samples was measured by determination of fatty acids methyl esters (FAMEs) that were prepared according to the AOAC method 948.22 [AOAC, 1990]. The analysis was performed by a gas chromatography Autosystem XL system (PerkinElmer, Inc., Waltham, MA, USA) equipped with a flame ionization detector. The FAMEs were separated using a $30 \mathrm{~m} \times 0.25 \mathrm{~mm} \times 0.25 \mu \mathrm{m}$ film, fused silica capillary column Supelcowax-10 (Sigma-Aldrich, Madrid, Spain). The carrier gas (hydrogen) flow rate was $0.8 \mathrm{~mL} /$ min. Injector and detector temperatures were $250^{\circ} \mathrm{C}$ and $270^{\circ} \mathrm{C}$, respectively. The oven temperature was programmed at $160^{\circ} \mathrm{C}$, followed by increases of $1^{\circ} \mathrm{C} / \mathrm{min}$ to reach $230^{\circ} \mathrm{C}$ and holding the temperature at $230^{\circ} \mathrm{C}$ for $65 \mathrm{~min}$. Injections $(2 \mu \mathrm{L})$ were made in the split mode (100:1). All measurements were done in triplicate. The content of individual fatty acids was calculated using methyl ester standard curves and expressed as $\mathrm{g} / 100 \mathrm{~g}$ of oil.

\section{Determination of amino acid profile and protein quality indexes}

Determination of protein amino acid profile was carried out by anaerobic acid hydrolysis, derivatization and HPLC quantification following the methodology described in Martinez-Villaluenga et al. [2010]. Tryptophan was determined by anaerobic alkaline hydrolysis, derivatization and HPLC according to the AOAC Official Method 988.15 [AOAC, 1990]. All measurements were done in two independent replicates. The content of individual amino acids was calculated using standard curves and expressed as $\mathrm{g} / 100 \mathrm{~g}$ of protein.

Chemical Score (CS) was calculated using the equation of Block \& Mitchel [1946], which compares the content of essential amino acids (EAA) of the test protein versus for the amount of the same amino acid of the reference (hen's egg protein). Limiting EAA corresponds to the amino acid having the lowest CS. EAA index (EAAI) estimates the quality of the test protein, using its EAA content as the criterion. EAAI was calculated according to the procedure of Oser [1959] that considers the ratio between EAA of the test protein and EAA of the reference protein, according to the following equation:

$$
\mathrm{EAAI}=\left[\left(\mathrm{a}^{1 / a^{1 s}}\right) \times\left(\mathrm{a}^{2} / \mathrm{a}^{2 \mathrm{~s}}\right) \times \ldots \times\left(\mathrm{a}^{\mathrm{n}} / \mathrm{a}^{\mathrm{ns}}\right]^{1 / \mathrm{n}}\right.
$$

where: $\mathrm{n}$ is the number of participating amino acids and ns is the number of corresponding amino acids in the standard. The biological value (BV) indicates the utilizable fraction of the test protein. BV was calculated using the equation of Oser [1959]: BV $=([1.09 \times \mathrm{EAAI}]-11.70)$. The protein efficiency ratio (PER) estimates the protein nutritional quality based on the amino acid profile after hydrolysis. PER was determined using the equation developed by Ihekoronye [1981]: PER $=-0.468+(0.454 \times[$ Leucine $])-(0.105 \times[$ Tyrosine]). The nutritional index (NI) normalizes the qualitative and quantitative variations of the test protein compared to its nutritional status. NI was calculated using the equation of Crisan \& Sands [1978]: NI = $($ EAAI $\times$ Protein $(\%) / 100)$.

\section{Qualitative and quantitative analyses of phenolic compounds}

Raw and treated samples (5 g) were macerated in methanol: TFA:water (79.999:0.001:20, v/v/v) at $4^{\circ} \mathrm{C}$ for $16 \mathrm{~h}$. Subsequently, they were centrifuged at $4,000 \times g$ and $5^{\circ} \mathrm{C}$ for $20 \mathrm{~min}$ in a Sorval RC 5B super-speed centrifuge (Fisher Scientific, Madrid, Spain). The extract was concentrated to dryness at $30^{\circ} \mathrm{C}$ under vacuum using a rotavapor (Bücchi Labortechnick, Flawil, Switzerland). For phenolic analysis, the dry extracts were dissolved in $10 \mathrm{~mL}$ of water. For purification, an aliquot (4 $\mathrm{mL}$ ) was passed through a C18 Sep-Pak cartridge (Waters, Milford, MA, USA), previously activated with methanol followed by water [Dueñas et al., 2008].

The HPLC analysis of the samples was performed using Hewlett-Packard 1100 system (Agilent Technologies, Palo Alto, CA, USA) coupled to an HP ChemStation (rev.A.0504) data-processing software. The separation conditions were exactly the same as described by Barros et al. [2012]. Detection was carried out by a diode array detector (DAD) at 280 and $370 \mathrm{~nm}$ as preferred wavelengths and a mass spectrophotometer (MS) connected to the HPLC system via the DAD cell outlet. An API 3200 Qtrap system (Applied Biosystems, Darmstadt, Germany) equipped with an ESI source, triple quadrupole-ion trap mass analyzer and controlled by the Analyst 5.1 software was used according to the method described by Barros et al. [2013].

Phenolic compounds were characterized according to their UV spectra, mass spectra, retention times, and comparison with authentic standards when available. For quantitative analysis, calibration curves were prepared by injection of known concentrations of standard compounds: vanillic acid, trans- $p$-coumaric acid, quercetin 3-O-rutinoside, quercetin 3-O-glucoside and kaempferol 3-O-rutinoside. Contents of hexosides and quinic derivatives of protocatechuic, vanillic, caffeic, ferulic and $p$-coumaric acids were calculated by external calibration curves of their corresponding free acids while contents of derivatives of quercetin and kaempferol were calculated by external calibration of kaempferol 3-O-glucoside and quercetin 3-O-glucoside. Data were expressed as $\mu \mathrm{g} / \mathrm{g}$ flour dw.

\section{Statistical analysis}

Means were compared by the analysis of variance (ANO$\mathrm{VA}$ ) adopting the standard criterion of significance at $\mathrm{P} \leq 0.05$. Statistical analysis was done using the general linear model (GLM) procedures of SAS/STAT R 9.2 (SAS Inst. Inc., Cary, NC, USA). Whenever differences were detected using the Tukey's test, treatment means were separated by pairwise comparisons of all possible pairwise differences among treatments. Homogeneity and normal distribution of the data were confirmed by analysis of the residuals using the UNIVARIATE function of SAS. P $\leq 0.05$ was used to declare differences among treatment means.

\section{RESULTS AND DISCUSSION}

Effect of puffing on macronutrients of kiwicha and quinoa

Table 1 shows proximate composition of raw and popped kiwicha and quinoa grains. The moisture, protein, lipid, ash and total carbohydrate contents of kiwicha grains were 
TABLE 1. Proximate composition of raw and popped kiwicha and quinoa grains*.

\begin{tabular}{l|c|c|c|c}
\hline \multirow{2}{*}{ Components } & \multicolumn{2}{|c|}{ Kiwicha } & \multicolumn{2}{c}{ Quinoa } \\
\cline { 2 - 5 } & Raw & Popped & Raw & Popped \\
\hline Moisture $(\mathrm{g} / 100 \mathrm{~g})$ & $9.39 \pm 0.01^{\mathrm{a}}$ & $4.38 \pm 0.01^{\mathrm{b}}$ & $9.54 \pm 0.10^{\mathrm{a}}$ & $11 \pm 0.01^{\mathrm{b}}$ \\
Total protein $(\mathrm{g} / 100 \mathrm{~g}$ dry weight) & $10.30 \pm 0.08^{\mathrm{b}}$ & $11.81 \pm 0.12^{\mathrm{a}}$ & $13.40 \pm 0.42^{\mathrm{a}}$ & $12.69 \pm 0.23^{\mathrm{b}}$ \\
Lipids $(\mathrm{g} / 100$ g dry weight) & $7.00 \pm 0.01^{\mathrm{b}}$ & $8.17 \pm 0.08^{\mathrm{a}}$ & $5.67 \pm 0.07^{\mathrm{b}}$ & $5.97 \pm 0.01^{\mathrm{a}}$ \\
Ash $(\mathrm{g} / 100$ g dry weight) & $2.58 \pm 0.02^{\mathrm{a}}$ & $2.65 \pm 0.05^{\mathrm{a}}$ & $2.43 \pm 0.04^{\mathrm{a}}$ & $2.21 \pm 0.02^{\mathrm{b}}$ \\
Carbohydrates $(\mathrm{g} / 100$ g dry weight) & $80.13 \pm 0.04^{\mathrm{a}}$ & $77.39 \pm 0.01^{\mathrm{b}}$ & $78.51 \pm 0.31^{\mathrm{b}}$ & $79.14 \pm 0.20^{\mathrm{a}}$ \\
\hline
\end{tabular}

*Mean \pm standard deviation of three replicates. Different lowercase letters within the same row indicate statistical differences between raw and popped grains $(\mathrm{P} \leq 0.05)$.

TABLE 2. Fatty acid composition (g/100 g oil) of raw and popped kiwicha and quinoa grains*.

\begin{tabular}{|c|c|c|c|c|}
\hline \multirow{2}{*}{ Fatty acids } & \multicolumn{2}{|c|}{ Kiwicha } & \multicolumn{2}{|c|}{ Quinoa } \\
\hline & Raw & Popped & Raw & Popped \\
\hline \multicolumn{5}{|c|}{ PUFA } \\
\hline Linoleic acid (C18:2 $\omega-6)$ & $40.76 \pm 0.01^{\mathrm{b}}$ & $40.26 \pm 0.13^{\mathrm{a}}$ & $50.94 \pm 0.05^{\mathrm{b}}$ & $50.52 \pm 0.08^{\mathrm{a}}$ \\
\hline$\alpha$-Linolenic acid $(\mathrm{C} 18: 3 \omega-3)$ & $0.61 \pm 0.02^{\mathrm{a}}$ & $0.62 \pm 0.01^{\mathrm{a}}$ & $7.28 \pm 0.02^{\mathrm{a}}$ & $7.19 \pm 0.00^{\mathrm{a}}$ \\
\hline Docosahexanoic acid (C22:6) & $7.46 \pm 0.01^{\mathrm{a}}$ & $6.76 \pm 0.54^{\mathrm{a}}$ & $1.71 \pm 0.01^{\mathrm{a}}$ & $1.84 \pm 0.02^{b}$ \\
\hline$\omega-6 / \omega-3$ & $66.89 \pm 3.12^{\mathrm{a}}$ & $64.96 \pm 1.12^{\mathrm{a}}$ & $7.00 \pm 0.04^{\mathrm{a}}$ & $7.03 \pm 0.02^{\mathrm{a}}$ \\
\hline Total & $48.83 \pm 0.05^{\mathrm{a}}$ & $47.64 \pm 0.68^{\mathrm{a}}$ & $59.93 \pm 0.08^{\mathrm{a}}$ & $59.55 \pm 0.10^{\mathrm{a}}$ \\
\hline \multicolumn{5}{|c|}{ MUFA } \\
\hline Palmitoleic acid (C16:1) & nd & nd & nd & $0.27 \pm 0.00$ \\
\hline Oleic acid (C18:1 cis-9) & $27.88 \pm 0.01^{\mathrm{a}}$ & $27.91 \pm 0.01^{\mathrm{a}}$ & $23.14 \pm 0.03^{\mathrm{a}}$ & $23.49 \pm 0.02^{\mathrm{b}}$ \\
\hline Vaccenic acid (C18:1 trans-11) & $0.905 \pm 0.01^{\mathrm{a}}$ & $0.95 \pm 0.01^{\mathrm{a}}$ & $1.235 \pm 0.02^{\mathrm{a}}$ & $1.22 \pm 0.01^{\mathrm{a}}$ \\
\hline Eicosanoic acid (C20:1) & $0.21 \pm 0.01^{\mathrm{a}}$ & $0.21 \pm 0.01^{\mathrm{a}}$ & $1.26 \pm 0.01^{\mathrm{a}}$ & $1.28 \pm 0.08^{\mathrm{a}}$ \\
\hline Erucic acid $(\mathrm{C} 22: 1 \omega-9)$ & nd & nd & nd & $1.37 \pm 0.19$ \\
\hline Cetoleic acid (C22:1) & nd & nd & $1.34 \pm 0.01$ & nd \\
\hline Total & $28.99 \pm 0.03^{\mathrm{a}}$ & $29.07 \pm 0.03^{\mathrm{a}}$ & $26.98 \pm 0.07^{\mathrm{a}}$ & $27.63 \pm 0.30^{\mathrm{a}}$ \\
\hline \multicolumn{5}{|c|}{ SFA } \\
\hline Arachidic acid (C20:0) & $0.79 \pm 0.01^{\mathrm{a}}$ & $0.87 \pm 0.05^{\mathrm{a}}$ & $0.37 \pm 0.01^{\mathrm{a}}$ & $0.34 \pm 0.01^{\mathrm{a}}$ \\
\hline Stearic acid (C18:0) & $3.64 \pm 0.01^{\mathrm{a}}$ & $3.60 \pm 0.02^{\mathrm{a}}$ & $0.41 \pm 0.06^{\mathrm{a}}$ & $0.45 \pm 0.00^{\mathrm{a}}$ \\
\hline Behenic acid (C22:0) & $0.27 \pm 0.01^{\mathrm{a}}$ & $0.31 \pm 0.04^{\mathrm{a}}$ & $0.50 \pm 0.01^{\mathrm{a}}$ & $0.44 \pm 0.05^{\mathrm{a}}$ \\
\hline Myristic acid (C14:0) & $0.19 \pm 0.01^{\mathrm{a}}$ & $0.20 \pm 0.01^{\mathrm{a}}$ & $0.26 \pm 0.01^{b}$ & $0.23 \pm 0.00^{\mathrm{a}}$ \\
\hline Palmitic acid (C16:0) & $17.16 \pm 0.01^{\mathrm{a}}$ & $17.18 \pm 0.52^{\mathrm{a}}$ & $11.20 \pm 0.02^{\mathrm{a}}$ & $11.16 \pm 0.10^{\mathrm{a}}$ \\
\hline Lignoceric acid (C24:0) & $0.16 \pm 0.01^{\mathrm{a}}$ & $0.20 \pm 0.04^{\mathrm{a}}$ & $0.24 \pm 0.01^{\mathrm{a}}$ & $0.22 \pm 0.01^{\mathrm{a}}$ \\
\hline Total & $22.21 \pm 0.05^{\mathrm{a}}$ & $22.36 \pm 0.72^{\mathrm{a}}$ & $12.98 \pm 0.12^{\mathrm{a}}$ & $12.85 \pm 0.17^{\mathrm{a}}$ \\
\hline
\end{tabular}

*Mean \pm standard deviation of three replicates. Different lowercase letters within the same row indicate statistical differences between raw and popped grains $(\mathrm{P} \leq 0.05)$. "nd" indicates "not detected".

PUFA, Polyunsaturated fatty acids; MUFA, Monounsaturated fatty acids; SFA, Saturated fatty acids.

$9.4 \mathrm{~g} / 100 \mathrm{~g}$ and $10.3,7.0,2.6$ and $80.1 \mathrm{~g} / 100 \mathrm{~g}$ dw, respectively, which was in accordance with literature data [Nascimento et al., 2014; Tang et al., 2016]. These values in quinoa grains were $9.5,13.4,5.7,2.4$ and $78.5 \mathrm{~g} / 100 \mathrm{~g} \mathrm{dw}$, respectively.
As expected, after the expansion process, moisture content of kiwicha was significantly reduced $(\mathrm{P} \leq 0.05)$ due to water evaporation. In addition, small changes in proximate composition of kiwicha were observed. Popped kiwicha showed 
slightly increased protein and lipid contents and lower amounts of total carbohydrates compared to raw grains $(\mathrm{P} \leq 0.05)$. However, ash content of kiwicha was not significantly affected by puffing ( $\mathrm{P}>0.05$ ). With respect to popped quinoa, slightly higher lipid and total carbohydrates contents $(\mathrm{P} \leq 0.05)$ were observed probably due to the concomitant decrease of crude protein and ash contents $(\mathrm{P} \leq 0.05)$. Similar results were reported in a previous study showing a small reduction in the protein content of amaranth grains after puffing [Amare et al., 2016]. Other cooking methods, such as streaming and boiling, have also shown impacts on mineral composition of pseudocereals with losses up to $20 \%$ [Mota et al., 2016], which is in consistency with our results showing a decrease in ash content during quinoa popping. This effect could be explained by partial thermal decomposition of amino acids [Yablokov et al., 2013].

\section{Effect of puffing on fatty acids composition of kiwicha and quinoa}

The effect of puffing on fatty acids profile of kiwicha and quinoa is reported in Table 2. Kiwicha and quinoa grain oil was mainly composed of polyunsaturated fatty acids (PUFA, 49 and $60 \mathrm{~g} / 100 \mathrm{~g}$ oil, respectively) followed by monounsaturated fatty acids (MUFA, 29 and $27 \mathrm{~g} / 100 \mathrm{~g}$ oil, respectively) and a minor content of saturated fatty acids (SFA, 22 and $13 \mathrm{~g} / 100 \mathrm{~g}$ oil, respectively). The contents of individual fatty acids were within the range reported in the literature for amaranth [Pasko et al., 2015; Peiretti et al., 2013] and quinoa [Tang et al., 2016]. Fatty acid profile of kiwicha and quinoa showed minimal differences after puffing. The fatty acid pattern in popped kiwicha was similar to raw grains. In the case of quinoa, only minor changes were observed after puffing such as the detection of small amounts of palmitic $(0.27 \mathrm{~g} / 100 \mathrm{~g}$ oil) and erucic acid ( $1.3 \mathrm{~g} / 100 \mathrm{~g}$ oil $)$ and the degradation of cetoleic acid. The main PUFA in both popped grains was linoleic acid (C18:2 $\omega-6)$, although it was found at a higher content in popped quinoa grains. Popped quinoa showed a content of $\alpha$-linolenic acid (C18:2 $\omega-3)$ 7-fold higher than popped kiwicha. Oleic acid (C18:1) was the second most abundant fatty acid in popped kiwicha and quinoa oils although it is worth noting that the former was richer in this MUFA. SFA content in popped kiwicha oil was almost 2-fold higher than the one found in popped quinoa. Palmitic acid (C16:0) was the third most abundant fatty acid found in both popped grains.

There is increasing evidence pointing out that unbalanced $\omega-6 / \omega-3$ ratio in favor of $\omega-6$ PUFAs is highly prothrombotic and proinflammatory, which contributes to the prevalence of atherosclerosis, obesity, and diabetes [Simopoulos, 2008; Kromhout \& de Goede, 2014]. In fact, regular consumption of diets rich in $\omega-3$ PUFAs has been associated with low incidence of these diseases [Kromann, \& Green, 1980; Adler et al., 1994; Schraer et al., 1999]. Puffing did not significantly $(\mathrm{P}>0.05)$ modify the $\omega-6 / \omega-3$ ratio of kiwicha and quinoa, although it is worth noting that considering the negative health impact of lipids with a high $\omega-6 / \omega-3$ ratio, popped and raw quinoa oil has a better nutritional quality than popped and raw kiwicha oil.

\section{Effect of puffing on amino acids profile and protein quality indexes of kiwicha and quinoa}

Amino acid profile of kiwicha and quinoa (Table 3) was similar to values reported in the literature [Mota et al., 2016]. Significant variations were found in some individual amino acids after puffing of kiwicha and quinoa grains. Popped kiwicha and quinoa grains showed a decrease in some non-essential and essential amino acids. Amino acid losses ranged from 17 to $31 \%$ and particularly affected to Arg, Ala, Pro, Val, Met, Cys, Ile, Phe, Tyr, Lys and Trp (Table 3, P $\leq 0.05$ ). Leu and sulfur amino acids (Met and Cys) were the first limiting amino acids of kiwicha and quinoa grains, respectively, in consistency with a recent study [Mota et al., 2016]; however, Val and Ile were the limiting amino acids in popped kiwicha and quinoa, respectively. Regarding protein quality indexes, it was observed that dry heating led to a slight decrease in EAAI, BV and NI $(\mathrm{P} \leq 0.05)$. In spite of these effects, thermal treatment did not affect the PER which reflects the capacity of a protein to support the body weight gain. Moreover, comparing the amino acid profile of popped kiwicha and quinoa to FAO/WHO suggested amino acid pattern recommended for adults (Table 3 ), it is observed that protein quality remained adequate after puffing.

Our results are similar to findings from previous studies showing a reduced amino acid content and protein quality of popped grains compared to untreated grains from different amaranth species [Pisariková et al., 2005; Gamel et al., 2004]. Reduction in amino acid content after puffing could be explained by thermally-induced chemical modifications of protein residues such as glycation, glycoxidation and oxidation. Thermally-induced Maillard reaction initially involves the condensation of the carbonyl moiety from a reducing sugar with protein amino groups at the N-terminus or Lys side chain [Arena et al., 2017]. Other sugar-independent modifications might occur in heated proteins including oxidative deamidation at the $\mathrm{N}$-terminal amino acid, $\beta$-elimination of Cys, and formation of lysinoalanine and histidinoalanine cross-linked derivatives [Arena et al., 2017].

\section{Effect of puffing of kiwicha and quinoa on phenolic profile}

Table 4 shows the phenolic composition of raw and popped kiwicha and quinoa grains. Hydroxybenzoic acids were the major group of phenolic compounds in raw kiwicha, representing $51 \%$ of the total phenolic content, followed by hydroxycinnamic acids accounting for approximately $34 \%$. Among flavonoid compounds, quercetin 3-O-rutinoside was the only flavonol detected in raw kiwicha, accounting for $15 \%$ of total phenolic content. The presence of some free hydroxybenzoic and hydroxycinnamic acids was previously reported in different kiwicha varieties [Barba de la Rosa et al., 2009; Klimczak et al., 2002]. The occurrence of hydroxybenzoic and hydroxycinnamic acids derivatives linked to hexoside and quinic acid has been recently identified in kiwicha [Paucar-Menacho et al., 2017].

The HPLC-DAD-ESI/MS analysis allowed the identification of 18 compounds in quinoa which belonged to hydroxybenzoic and hydroxycinnamic acids (free and de- 
TABLE 3. Total amino acid content (g/100g protein) and protein quality indexes of raw and popped kiwicha and quinoa grains*.

\begin{tabular}{|c|c|c|c|c|c|}
\hline \multirow{2}{*}{ Suggested pattern for adults } & & \multicolumn{2}{|c|}{ Kiwicha } & \multicolumn{2}{|c|}{ Quinoa } \\
\hline & & Raw & Popped & Raw & Popped \\
\hline \multicolumn{6}{|c|}{ Non-essential amino acids } \\
\hline Asx & & $8.74 \pm 0.14^{\mathrm{a}}$ & $7.92 \pm 0.56^{\mathrm{a}}$ & $9.44 \pm 0.11^{\mathrm{a}}$ & $9.52 \pm 0.84^{\mathrm{a}}$ \\
\hline Glx & & $17.64 \pm 0.17^{\mathrm{a}}$ & $17.82 \pm 1.20^{\mathrm{a}}$ & $16.79 \pm 0.47^{\mathrm{a}}$ & $17.80 \pm 0.78^{\mathrm{a}}$ \\
\hline Ser & & $6.66 \pm 0.15^{\mathrm{a}}$ & $6.58 \pm 0.64^{\mathrm{a}}$ & $4.79 \pm 0.13^{\mathrm{a}}$ & $5.06 \pm 0.39^{\mathrm{a}}$ \\
\hline Gly & & $8.95 \pm 0.10^{\mathrm{a}}$ & $8.14 \pm 0.58^{\mathrm{a}}$ & $6.40 \pm 0.18^{\mathrm{a}}$ & $5.62 \pm 0.35^{\mathrm{b}}$ \\
\hline Arg & & $9.86 \pm 0.26^{\mathrm{a}}$ & $8.18 \pm 0.79^{b}$ & $10.85 \pm 0.30^{\mathrm{a}}$ & $9.86 \pm 0.41^{\mathrm{b}}$ \\
\hline Ala & & $4.51 \pm 0.08^{\mathrm{a}}$ & $3.72 \pm 0.24^{\mathrm{b}}$ & $4.67 \pm 0.27^{\mathrm{a}}$ & $3.85 \pm 0.01^{\mathrm{b}}$ \\
\hline Pro & & $4.69 \pm 0.12^{\mathrm{b}}$ & $3.43 \pm 0.24^{\mathrm{a}}$ & $4.76 \pm 0.09^{\mathrm{a}}$ & $3.67 \pm 0.39^{\mathrm{b}}$ \\
\hline \multicolumn{6}{|c|}{ Essential amino acids (EAA) } \\
\hline His & 1.5 & $2.55 \pm 0.09^{\mathrm{a}}$ & $2.33 \pm 0.24^{\mathrm{a}}$ & $2.97 \pm 0.11^{\mathrm{a}}$ & $2.50 \pm 0.24^{\mathrm{b}}$ \\
\hline Val & 3.9 & $5.35 \pm 0.09^{\mathrm{a}}$ & $3.42 \pm 0.24^{\mathrm{b}}$ & $6.37 \pm 0.13^{\mathrm{a}}$ & $3.87 \pm 0.08^{b}$ \\
\hline Met & 1.6 & $2.77 \pm 0.08^{\mathrm{a}}$ & $1.83 \pm 0.11^{\mathrm{b}}$ & $1.98 \pm 0.05^{\mathrm{a}}$ & $1.24 \pm 0.06^{\mathrm{b}}$ \\
\hline Cys & 0.6 & $3.05 \pm 0.08^{\mathrm{a}}$ & $2.41 \pm 0.21^{\mathrm{b}}$ & $2.01 \pm 0.35^{\mathrm{a}}$ & $1.84 \pm 0.07^{\mathrm{b}}$ \\
\hline Ile & 3.0 & $4.04 \pm 0.03^{\mathrm{a}}$ & $2.88 \pm 0.13^{\mathrm{b}}$ & $4.64 \pm 0.24^{\mathrm{a}}$ & $3.16 \pm 0.12^{\mathrm{b}}$ \\
\hline Leu & 5.9 & $6.12 \pm 0.16^{\mathrm{a}}$ & $5.77 \pm 0.24^{\mathrm{a}}$ & $7.39 \pm 0.39^{\mathrm{a}}$ & $6.98 \pm 0.17^{\mathrm{a}}$ \\
\hline Phe & \multirow{2}{*}{$3.8^{* *}$} & $4.34 \pm 0.03^{\mathrm{a}}$ & $3.29 \pm 0.08^{\mathrm{b}}$ & $4.71 \pm 0.07^{\mathrm{a}}$ & $3.28 \pm 0.24^{\mathrm{b}}$ \\
\hline Tyr & & $4.33 \pm 0.11^{\mathrm{a}}$ & $3.17 \pm 0.12^{\mathrm{b}}$ & $4.20 \pm 0.10^{\mathrm{a}}$ & $2.86 \pm 0.28^{\mathrm{b}}$ \\
\hline Lys & 4.5 & $6.28 \pm 0.12^{\mathrm{a}}$ & $4.61 \pm 0.30^{\mathrm{b}}$ & $6.38 \pm 0.44^{\mathrm{a}}$ & $4.96 \pm 0.08^{\mathrm{b}}$ \\
\hline Thr & 2.3 & $3.47 \pm 0.07^{\mathrm{a}}$ & $3.35 \pm 0.26^{\mathrm{a}}$ & $3.84 \pm 0.11^{\mathrm{a}}$ & $3.38 \pm 0.17^{\mathrm{a}}$ \\
\hline Trp & 0.6 & $1.75 \pm 0.22^{\mathrm{a}}$ & $1.31 \pm 0.02^{\mathrm{b}}$ & $1.42 \pm 0.29^{\mathrm{a}}$ & $1.37 \pm 0.19^{\mathrm{b}}$ \\
\hline Limiting essential amino acids $\#$ & & Leu $(71.22)$ & Val (52.5) & Met+Cys (70.0) & Ile (58.5) \\
\hline Essential amino acid index (EAAI) & & $68.59 \pm 0.22^{\mathrm{a}}$ & $62.85 \pm 0.78^{\mathrm{b}}$ & $69.95 \pm 0.70^{\mathrm{a}}$ & $65.26 \pm 0.59^{\mathrm{b}}$ \\
\hline Biological value (BV) & & $63.07 \pm 0.24^{\mathrm{a}}$ & $56.81 \pm 0.84^{\mathrm{b}}$ & $64.54 \pm 0.77^{\mathrm{a}}$ & $59.44 \pm 0.64^{\mathrm{b}}$ \\
\hline Protein efficiency ratio (PER) & & $1.86 \pm 0.06^{\mathrm{a}}$ & $1.82 \pm 0.09^{\mathrm{a}}$ & $2.45 \pm 0.17^{\mathrm{a}}$ & $2.40 \pm 0.10^{\mathrm{a}}$ \\
\hline Nutritional index (NI) & & $9.19 \pm 0.03^{\mathrm{a}}$ & $7.98 \pm 0.10^{\mathrm{b}}$ & $9.37 \pm 0.09^{\mathrm{a}}$ & $8.28 \pm 0.07^{\mathrm{b}}$ \\
\hline
\end{tabular}

*Mean \pm standard deviation of three replicates. Different lowercase letters within the same row indicate statistical differences between raw and popped grains $(\mathrm{P} \leq 0.05)$.

FAO/WHO suggested amino acid pattern for adults (g/100g protein) [FAO, 2011]. "Suggested composition for aromatic amino acids Phe+Tyr [FAO, 2011]. \#Values in parenthesis indicate chemical score (CS) values for the limiting EAA in raw and popped kiwicha and quinoa grains.

rivatives) as well as flavonols (quercetin and kaempferol glycosides) (Table 4). Flavonols were the most abundant compounds $(78 \%)$, followed by hydroxycinnamic acids (17\%) and hydroxybenzoic acids $(5 \%)$. These results agree with those reported by Gómez-Caravaca et al. [2011] who identified different free phenolic compounds including hydroxybenzoic acids including vanillic glucoside as well as a number of kaempferol and quercetin derivatives (kaempfer$\mathrm{ol}$ and quercetin 3-O-apifuranosyl-galactopyranoside, quercetin $O$-glucuronide and others) in different quinoa varieties. In addition, different bound phenolic acids, such as vanillic, $p$-coumaric and ferulic acids, were reported in quinoa [Gómez-Caravaca et al., 2011].
Notable qualitative and quantitative differences in phenolic compounds were observed after puffing of kiwicha and quinoa (Table 4). Puffing decreased the content of total hydroxycinnamic acids in kiwicha (22\%) and quinoa (35\%) $(\mathrm{P} \leq 0.05)$. Feruloylquinic acid, caffeoylquinic acid and caffeic acid derivatives were the main compounds negatively affected by puffing in kiwicha while trans-p-coumaric acid was the main compound notably reduced $(57 \%)$ in quinoa. In contrast, a notable increase was observed for contents of other phenolic compounds after puffing. This was the case of trans-feruloyl hexoside acid and trans-p-coumaric acid that were found at a higher content in popped kiwicha grains (26\% and 69\% increase, respectively). The amount 
TABLE 4. Contents of individual phenolic compounds ( $\mu \mathrm{g} / \mathrm{g}$ dry weight) in raw and popped kiwicha and quinoa grains*.

\begin{tabular}{|c|c|c|c|c|}
\hline \multirow{2}{*}{ Compounds } & \multicolumn{2}{|c|}{ Kiwicha } & \multicolumn{2}{|c|}{ Quinoa } \\
\hline & Raw & Popped & Raw & Popped \\
\hline Protocatechuic hexoside acid & $0.56 \pm 0.08$ & nd & nd & nd \\
\hline Vanillic pentoside acid & $3.03 \pm 0.08^{\mathrm{a}}$ & $3.73 \pm 0.96^{\mathrm{a}}$ & nd & nd \\
\hline Feruloylquinic acid & $0.25 \pm 0.04$ & nd & nd & nd \\
\hline trans-Feruloyl hexoside acid & $1.30 \pm 0.12^{\mathrm{b}}$ & $1.76 \pm 0.17^{\mathrm{a}}$ & nd & nd \\
\hline Vanillic acid & $3.79 \pm 0.84^{\mathrm{a}}$ & $2.69 \pm 0.66^{\mathrm{b}}$ & $2.64 \pm 0.26^{\mathrm{a}}$ & $2.22 \pm 0.46^{\mathrm{a}}$ \\
\hline Caffeoylquinic acid & $2.32 \pm 0.19$ & nd & nd & nd \\
\hline trans-p-Coumaric acid & $0.32 \pm 0.04^{\mathrm{b}}$ & $1.04 \pm 0.15^{\mathrm{a}}$ & $68.10 \pm 0.37^{\mathrm{a}}$ & $29.57 \pm 4.96^{\mathrm{b}}$ \\
\hline Caffeic acid derivative & $0.73 \pm 0.00$ & nd & nd & nd \\
\hline Vanillic hexoside acid & nd & nd & $5.11 \pm 0.48$ & $\mathrm{t}$ \\
\hline Vanillic acid derivative & nd & nd & $26.72 \pm 1.20^{\mathrm{b}}$ & $31.37 \pm 2.42^{\mathrm{a}}$ \\
\hline Quercetin 3-O-rutinoside & $2.15 \pm 0.09^{\mathrm{a}}$ & $0.83 \pm 0.02^{\mathrm{b}}$ & $73.33 \pm 0.74^{b}$ & $112.60 \pm 0.67^{\mathrm{a}}$ \\
\hline $\begin{array}{l}\text { Quercetin dirhamnopiranosyl- } \\
\text { galactopyranoside }\end{array}$ & nd & nd & $226.76 \pm 0.30^{a}$ & $212.06 \pm 1.35^{\mathrm{b}}$ \\
\hline Ferulic acid derivative (I) & nd & nd & $18.66 \pm 0.05^{\mathrm{a}}$ & $15.46 \pm 0.22^{b}$ \\
\hline Ferulic acid derivative (II) & nd & nd & $30.20 \pm 0.17^{\mathrm{a}}$ & $31.43 \pm 2.03^{\mathrm{a}}$ \\
\hline Quercetin rhamnosyl glucuronide & nd & nd & $8.82 \pm 0.43^{b}$ & $15.90 \pm 0.47^{\mathrm{a}}$ \\
\hline Quercetin rhamnosyl hexoside & nd & nd & $23.50 \pm 0.00^{\mathrm{b}}$ & $32.24 \pm 3.13^{\mathrm{a}}$ \\
\hline Quercetin apiofuranosyl galactopyranoside & nd & nd & $43.99 \pm 0.42^{b}$ & $59.36 \pm 0.57^{a}$ \\
\hline Kaempferol dirhamnosyl-galactopyranose & nd & nd & $13.92 \pm 0.52^{\mathrm{a}}$ & $6.75 \pm 0.88^{b}$ \\
\hline Quercetin glucuronide & nd & nd & $48.09 \pm 1.34^{b}$ & $99.12 \pm 3.81^{\mathrm{a}}$ \\
\hline Quercetin 3-O-glucoside & nd & nd & $12.38 \pm 0.53^{b}$ & $39.11 \pm 2.18^{\mathrm{a}}$ \\
\hline $\begin{array}{l}\text { Kaempferol apiofuranosyl } \\
\text { rhamnopyranosyl-galactoside }\end{array}$ & nd & nd & $46.81 \pm 1.86^{\mathrm{a}}$ & $47.96 \pm 1.34^{\mathrm{a}}$ \\
\hline Kaempferol rhamnosyl glucuronide & nd & nd & $22.85 \pm 1.38^{\mathrm{b}}$ & $28.87 \pm 0.89^{\mathrm{a}}$ \\
\hline Kaempferol 3-O-rutinoside & nd & nd & $9.00 \pm 0.20^{\mathrm{b}}$ & $13.50 \pm 0.15^{\mathrm{a}}$ \\
\hline Kaempferol glucuronide & nd & nd & $5.53 \pm 0.80^{\mathrm{b}}$ & $7.12 \pm 0.13^{\mathrm{a}}$ \\
\hline Phenolic acids & $12.30 \pm 1.35^{\mathrm{a}}$ & $9.93 \pm 1.86^{b}$ & $151.43 \pm 1.22^{\mathrm{a}}$ & $110.05 \pm 5.24^{b}$ \\
\hline Flavonoids & $2.15 \pm 0.09^{a}$ & $0.83 \pm 0.02^{b}$ & $534.99 \pm 4.13^{b}$ & $674.58 \pm 0.35^{\mathrm{a}}$ \\
\hline Total & $14.45 \pm 0.90^{\mathrm{a}}$ & $10.76 \pm 2.10^{\mathrm{b}}$ & $686.42 \pm 5.35^{b}$ & $784.63 \pm 5.13^{\mathrm{a}}$ \\
\hline
\end{tabular}

*Mean \pm standard deviation of three replicates. Different lowercase letters within the same row indicate statistical differences between raw and popped grains $(\mathrm{P} \leq 0.05)$. "t" indicates "traces". "nd" indicates "not detected".

of hydroxybenzoic acids was significantly reduced (13\%) after dry heat treatment in kiwicha, in which protocatechuic hexoside and vanillic acid were not detected. In the case of quinoa, puffing caused a slightly lower reduction (2.6\%) of the content of this class of phenolic compounds $(\mathrm{P} \leq 0.05)$. On the contrary, vanillic acid derivative was found at a higher content (15\% increase) in popped quinoa than in raw grains $(\mathrm{P} \leq 0.05)$. In summary, dry heat puffing brought about a general decrease in contents of hydroxybenzoic and hydroxycinnamic acids in both pseudocereal species, which might be explained by thermally-induced degradation of phenolic compounds [Ogrodowska et al., 2012].
The most outstanding variations found as consequence of dry heat puffing were those that occurred in the flavonoid group. The content of flavonol quercetin 3-O-rutinoside decreased significantly $(\mathrm{P} \leq 0.05)$ in popped kiwicha $(61 \%)$ compared to the control (Table 4). On the contrary, popped quinoa grains showed a higher total flavonols content (21\% increase) than raw grains $(\mathrm{P} \leq 0.05$, Table 4$)$. Interestingly, the amount of quercetin 3-O-glucoside and quercetin glucuronide increased by $68 \%$ and $51 \%$ in popped quinoa. This increase could be attributed to the enhanced extractability of bound flavonoid compounds as a consequence of heat-induced disruption of the plant cell wall [Muyonga et al., 2014]. Puffing 
caused a significant decrease in total phenolic content in kiwicha while opposite effects were observed for quinoa in which total phenolic content was markedly increased $(\mathrm{P} \leq 0.05)$. Our results are consistent with earlier studies showing losses in the total phenolic content (measured by the colorimetric Folin-Ciocalteu method) after puffing of different varieties of amaranth [Muyonga et al., 2014; Chaires-Martinez et al., 2013; Gamel et al., 2006; Ogrodowska et al., 2012]. Similarly, thermal cooking methods, such as boiling and baking, have shown to reduce total phenolic contents of quinoa and amaranth products [Rocchetti et al., 2017; Alvárez-Jubete et al., 2010]. Although thermal cooking reduces total phenolic compounds, bioavailability of phenolics is improved as it has been recently demonstrated by Rocchetti et al. [2017] who observed a reduction of bound-to-free ratio of phenolic compounds in cooked quinoa pasta.

\section{CONCLUSIONS}

This work demonstrated that popped grains retained in a great extent their nutritional profile. Amino acids, hydroxycinnamic and hydroxybenzoic acids were the main compounds affected by dry heating. Despite EAA degradation, it was observed that protein amino acid composition was of adequate quality. Interestingly, dry heat puffing of quinoa grains enhanced the release of flavonols from the food matrix, which is of special relevance in flavonoids bioavailability. In summary, puffing kiwicha and quinoa grains is an alternative processing method to obtain expanded products or precooked flours of adequate nutritional value.

\section{RESEARCH FUNDING AND ACKNOWLEDGEMENTS}

This work was supported by the Ministry of Economy and Competitiveness (MINECO, Spain) and FEDER programme from the European Commission (grant number AGL2013-43247-R). E. P. acknowledges the MINECO and European Social Fund for her "Ramón y Cajal" grant. L. P-M. acknowledges the Consejo Nacional de Ciencia y Tecnología (CONCYTEC, Perú) for financial support.

\section{REFERENCES}

1. Adler A.I., Boyko E.J., Schraer C.D., Murphy N.J., Lower prevalence of impaired glucose tolerance and diabetes associated with daily seal oil or salmon consumption among Alaska Natives. Diabetes Care, 1994, 17, 1498-1501.

2. Alvarez-Jubete L., Wijngaard H.E., Arendt K., Gallagher E., Polyphenol composition and in vitro antioxidant activity of amaranth, quinoa buckwheat and wheat as affected by sprouting and baking. Food Chem., 2010, 119, 770-778.

3. Amare E., Mouquet-Rivier C., Rochette I., Adish A., Haki G.D., Effect of popping and fermentation on proximate composition, minerals and absorption inhibitors, and mineral bioavailability of Amaranthus caudatus grain cultivated in Ethiopia. J. Food Sci. Tech. Mysore, 2016, 3, 2987-2994.

4. AOAC. Fatty acids in oils and fats, preparation of methyl esters. Official Method 969.33. in: Official Methods of Analysis $15^{\text {th }}$ ed., 1990, AOAC International, Arlington, Arlington, Virginia.
5. AOAC. Official Methods of Analysis of AOAC International, $18^{\text {th }}$ ed. 2005, AOAC International, Gaithersburg, MD, USA.

6. Arena S., Renzone G., D’Ambrosio C., Salzano A.M., Scaloni A., Dairy products and the Maillard reaction: A promising future for extensive food characterization by integrated proteomics studies. Food Chem., 2017, 219, 477-489.

7. Barba de la Rosa A.P., Fomsgaard I., Laursen B., Mortensen A.G., Olvera-Martinez L., Silva-Sánchez C., Mendoza-Herrera A., González-Castañeda J., De León-Rodríguez A. Amaranth (Amaranthus hypochondriacus) as an alternative crop for sustainable food production: Phenolic acids and flavonoids with potential impact on its nutraceutical quality. J. Cereal Sci., 2009, 49, 117-121.

8. Barros L., Dueñas M., Carvalho A.M., Ferreira I.C.F.R., Santos-Buelga C., Characterization of phenolic compounds in flowers of wild medicinal plants from Northeastern Portugal. Food Chem. Toxicol., 2012, 50, 1576-1582.

9. Barros L., Dueñas M., Dias M.I., Sousa M.J., Santos-Buelga C., Ferreira, I.C.F.R., Phenolic profiles of cultivated, in vitro cultured and commercial samples of Melissa officinalis L. infusion. Food Chem., 2013, 136, 1-8.

10. Block R.J., Mitchel H.H., The correlation of the amino acid composition of protein with their nutritive value. Nutr. Abstracts Rev., 1946, 16, 249-278.

11. Chaires-Martinez L., Perez-Vargas M.A., Cantor del Angel A.I., Cruz-Bermudez F., Jiménez-Avalos H.A., Total phenolic content and antioxidant capacity of germinated, popped and cooked Huauzontle (Chenopodium berlandieri spp. nuttalliae) seeds. Cereal Chem., 2013, 90, 263-268.

12. Crisan E.V., Sands A., Nutritional value. 1978, in: The Biology and Cultivation of Edible Mushrooms (eds. S.T. Chang, W.A. Hayes). Academic Press, New York, pp. 137-165.

13. de la Barca A.M.C., Rojas-Martínez M.E., Islas-Rubio A.R., Cabrera-Chávez F., Gluten-Free breads and cookies of raw and popped amaranth flours with attractive technological and nutritional qualities. Plant Foods Human Nutr., 2010, 65, 241-246.

14. Dueñas M., Pérez-Alonso J.J., Santos-Buelga C., Escribano-Bailón M.T., Anthocyanin composition in fig (Ficus carica L.). J. Food Comp. Anal., 2008, 21, 107-115.

15. FAO. 2011. Quinoa: an ancient crop to contribute to world food security. Available from: [http://www.fao.org/docrep/017/ aq287c/aq287e.pdf]. Accessed 2016 August 25th.

16. Gamel T.H., Linssen J.P., Alink G.M., Mossallem A.S., Shekib L.A., Nutritional study of raw and popped seed proteins of Amaranthus caudatus L. and Amaranthus cruentus L. J. Sci. Food Agric., 2004, 84, 1153-1158.

17. Gamel T.H., Linssen J.P., Mesallam A.S., Damir A.A., Shekib L.A., Seed treatments affect functional and antinutritional properties of amaranth flours. J. Sci. Food Agric., 2006, 86, 1095-1102.

18. Gamel T.H., Linssen J.P.H., Flavor compounds of popped amaranth seed. J. Food Process. Preserv., 2008,32, 656-668.

19. Gómez-Caravaca A.M., Segura-Carretero A., Fernández-Gutíerrez A., Caboni M.F., Simultaneous determination of phenolic compounds and saponins in Quinoa (Chenopodium quinoa Willd) by a liquid chromatography-diode array detection-electrospray ionization-time of flight mass spectrometry methodology. J. Agric. Food Chem., 2011, 59, 10815-10825. 
20. Hoke K., Houška M., Průchová J., Gabrovská D., Vaculová K., Paulíčková I., Optimisation of puffing naked barley. J. Food Eng., 80, 2007, 1016-1022.

21. Ihekoronye A.I., 1981. A rapid enzymatic and chromatographic predictive model for the in vivo rat based protein efficiency ratio (PhD thesis). University of Missouri, Columbia.

22. Klimczak M., Malecka M., Pacholek B., Antioxidant activity of ethanolic extracts of amaranth seeds. Nahrung - Food, 2002, 46, 184-186.

23. Kromann N., Green A., Epidemiological studies in the Upernavik district, Greenland. Incidence of some chronic diseases 1950-1974. Acta Med. Scand., 1980, 208, 401-406.

24. Kromhout D., de Goede J., Update on cardiometabolic health effects of $\omega-3$ fatty acids. Curr. Opin. Lipidol., 2014, 25, 85-90.

25. Lamothe L.M., Srichuwong S., Reuhs B.L., Hamaker B.R., Quinoa (Chenopodium quinoa W.) and amaranth (Amaranthus caudatus L.) provide dietary fibres high in pectic substances and xyloglucans. Food Chem., 2015, 167, 490-496.

26. Martinez-Villaluenga C., Torres A., Frias J., Vidal-Valverde C., Semolina supplementation with processed lupin and pigeon pea flours improves protein quality of pasta. LWT - Food Sci. Technol., 2010, 43, 617-622.

27. Mota C., Nascimento A.C., Santos M., Delgado I., Coelho I., Rego A., Matos A.S., Torres D., Castanheira I., The effect of cooking methods on the mineral content of quinoa (Chenopodium quinoa), amaranth (Amaranthus sp.) and buckwheat (Fagopyrum esculentum). J. Food Comp. Anal., 2016, 49, 57-64.

28. Mota C., Santos M., Mauro R., Samman N., Matos A.S., Torres D., Castanheira I., Protein content and amino acids profile of pseudocereals. Food Chem., 2016, 193, 55-61.

29. Murakami T., Yutani A., Yamano T., Iyota H., Konishi Y., Effects of popping on nutrient contents of amaranth seed. Plant Foods Hum. Nutr., 2014, 69, 25-29.

30. Muyonga J.H., Andabati B., Ssepuuya G., Effect of heat processing on selected grain amaranth physicochemical properties. Food Sci. Nutr., 2014, 2, 9-16.

31. Nascimento A.C., Mota C., Coelho I., Gueifão S., Santos M., Matos A.S., Lobo M., Samman N., Castanheira I., Characterisation of nutrient profile of quinoa (Chenopodium quinoa), amaranth (Amaranthus caudatus), and purple corn (Zea mays L.) consumed in the North of Argentina: Proximates, minerals and trace elements. Food Chem., 2014, 148, 420-426.

32. Ogrodowska D., Czaplicki S., Zadernowski R., Mattila P., Hellstrom J., Naczk M., Phenolic acids in seeds and products obtained from Amaranthus cruentus. J. Food Nutr. Res., 2012, 51, 96-101.

33. Oser B.L., An integrated essential amino acid index for predicting the biological value of proteins. 1959, in: Protein and Amino Acids in Nutrition (ed. A.A. Albanese). Academic Press, New York, pp. 281-291.

34. Pasko P., Gdula-Argainska J., Podporska-Carroll J., Quilty B., Wietecha-Posluszny R., Tyszka-Czochara M., Zagrodzki P., Influence of selenium supplementation of fatty acids profile and biological activity of four edible amaranth sprouts as new kind of functional food. J. Food Sci. Technol. Mysore, 2015, 52, 4724-4736.
35. Paucar-Menacho L.M., Peñas E., Dueñas M., Frias J., Martinez-Villaluenga C., Optimizing germination conditions to enhance the accumulation of bioactive compounds and the antioxidant activity of kiwicha (Amaranthus caudatus) using response surface methodology. LWT - Food Sci. Technol., 2017, 76, SI, 245-252.

36. Peiretti P.G., Gai F., Tassone S., Fatty acid profile and nutritive value of quinoa (Chenopodium quinoa Willd.) seeds and plants at different growth stages. Anim. Feed Sci. Tech., 2013, 183, 56-61.

37. Pisariková B., Kracmar S., Herzig I., Amino acid contents and biological value of protein in various amaranth species. Czech J. Anim. Sci., 2005, 50, 169-174.

38. Repo-Carrasco R., Espinoza C., Jacobsen S-E., Nutritional value and use of the Andean crops quinoa (Chenopodium quinoa) and kañiwa (Chenopodium pallidicaule). Food Rev. Int., 2003, 19, 179-189.

39. Rocchetti G., Lucini L., Chiodelli G., Giuberti G., Montesano D., Masoero F., Trevisan M., Impact of boiling on free and bound phenolic profile and antioxidant activity of commercial glutenfree pasta. Food Res. Int., 2017, 100, 69-77.

40. Ruales J., Nair B.M., Nutritional quality of the protein in quinoa (Chenopodium quinoa Willd.) seeds. Plant Foods Hum. Nutr., 1992, 42, 1-11.

41. Schraer C.D., Risica P.M., Ebbesson S.O., Go O.T., Howard B.V., Mayer A.M., Low fasting insulin levels in Eskimos compared to American Indians: are Eskimos less insulin resistant? Int. J. Circum. Health, 1999, 58, 272-280.

42. Simopoulos A.P., The importance of the omega-6/omega-3 fatty acid ratio in cardiovascular disease and other chronic diseases. Exp. Biol. Med., 2008, 233, 674-688.

43. Song A., Eckhoff S.R., Optimum popping moisture content for popcorn kernels of different sizes. Cereal Chem., 1994, 71, 458-460.

44. Tang Y., Li X., Chen P.X., Zhang B., Hernandez M., Zhang H., Marcone M.F., Liu R., Tsao R., Characterisation of fatty acid, carotenoid, tocopherol/tocotrienol compositions and antioxidant activities in seeds of three Chenopodium quinoa Willd. genotypes. Food Chem., 2015, 174, 502-508.

45. Tang Y., Li X., Chen P.X., Zhang B., Liu R., Hernandez M., Marcone M.F., Tsao R., Assessing the fatty acid, carotenoid, and tocopherol compositions of amaranth and quinoa seeds grown in Ontario and their overall contribution to nutritional quality. J. Agric. Food Chem., 2016, 64, 1103-1110.

46. Taylor J., Belton P., Beta T., Duodu K., Increasing the utilisation of sorghum, millets and pseudocereals: Developments in the science of their phenolic phytochemicals, biofortification and protein functionality. J. Cereal Sci., 2014, 59, 257-275.

47. USDA. National nutrient database for standard reference. United States Department of Agriculture. 2016. Press Release 28.

48. Yablokov V.A., Smel'tsova I.L., Faerman, V.I., Thermal stability of amino acids. Russ. J. Gen. Chem., 2013, 83, 476-480.

49. Zapotoczny P., Markowski M., Majewska K., Ratajski A., Konopko H., Effect of temperature on the physical, functional, and mechanical characteristics of hot-air-puffed amaranth seeds. J. Food Eng., 2006, 76, 469-476.

Submitted: 7 September 2017. Revised: 23 November 2017. Accepted: 13 December 2017. Published on-line: 28 March 2018. 